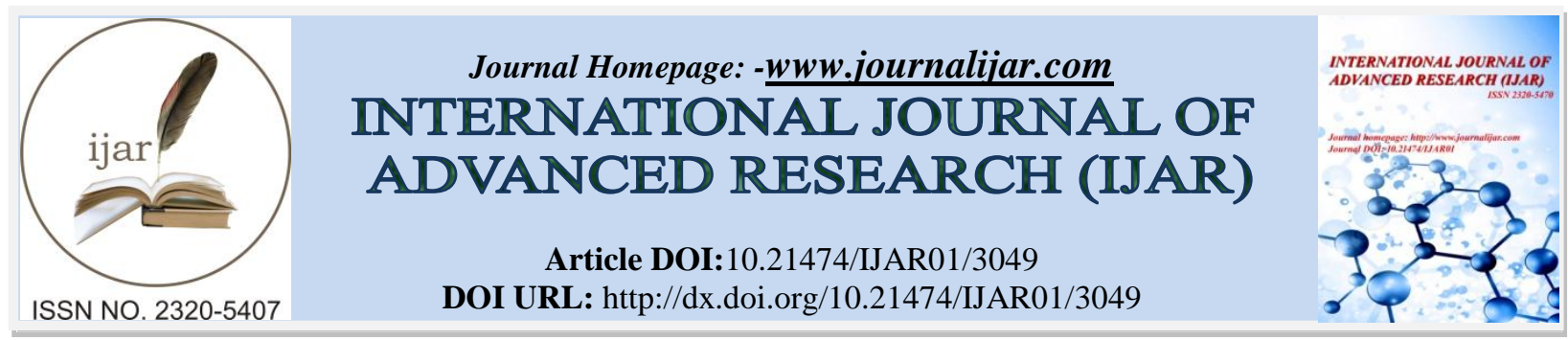

RESEARCH ARTICLE

\title{
EFFECT OF THE METHANOLIC LEAF EXTRACT OF BOSWELLIA DALZIELII HUTCH ON THE LIVER INTEGRITY OF SELENITE-INDUCED CATARACT PUPS.
}

\author{
Divine A. Onobrudu*, Eugene N. Onyeike and Jude C. Ikewuchi. \\ Institutional Affiliation: Department of Biochemistry, Faculty of Science, University of Port- Harcourt, P.M.B 5323, \\ Port-Harcourt, Nigeria.
}

\section{Manuscript Info}

Manuscript History

Received: 30 November 2016

Final Accepted: 28 December 2016

Published: January 2017

Key words:-

Sodium-selenite, Cataract,Boswellia dalzielii Hutch, Liver, Reflotron, Liver function enzymes.

\begin{abstract}
The effect of Boswellia dalzielii Hutch extract on the liver integrity of selenite-induced cataract pups was investigated. Nine groups of five pups each were used for this study. Group 1 received normal saline, groups 2 to 9 received $30 \mu \mathrm{mol} / \mathrm{kg}$ BW of sodium selenite. Eight days post administration of selenite, the presence of cataract was confirmed with the aid of an ophthalmoscope, after which the treatment commenced and lasted for 28 days. The extract significantly $(\mathrm{p}<0.05)$ lowered alkaline phosphatase activity and total bilirubin concentration. The obtained results infer that $B$. dalzielii Hutch leaf extract had no harmful effect on the liver integrity of selenite-induced cataract pups.
\end{abstract}

Copy Right, IJAR, 2016,. All rights reserved.

\section{Introduction:-}

The liver is an organ of great importance which plays an essential role in metabolism of xenobiotics and toxins in the body (Onoriose et al., 2012). Strinath et al (2010) reported that such compounds produce a wide variety of toxic metabolites which adversely affect the functions and integrity of the liver. Prolong intake as well as over dosage of some drug and toxins stimulate oxidative stress and liver injury. Quantitative determination of the liver function parameters are essential pointer to the level and type of liver disorder (Rekha et al., 2009). Because detoxification of xenobiotics and toxins are functions of the liver, damageto the liver becomes a major health challenge (Mitra $e t$ al., 1998).

Boswellia dalzielii Hutch is a savannah tree which belong to the family of Burseraceae (Younoussa et al., 2014) and it is mostly called the "Frankincense tree" (Sani and Qamar, 2015).The qualitative and quantitative phytochemical analysis of the leaves reveal the presence of flavonoids, saponins, steroids, glycosides, tannins, terpenoids, alkaloids, balsam and resins (Onoriose, 2012; Uzama et al., 2015). Uzama et al(2015) reported that the proximate analysis of the leaf revealed: moisture $12.24 \%$, ash $7.43 \%$, crude fibre $32.85 \%$, crude lipids $20.41 \%$, crude protein $1.00 \%$ and carbohydrate $26.07 \%$. That of the bark is: a moisture of $8.51 \%$, ash $14.23 \%$, crude fibre $42.86 \%$, crude lipid $14.23 \%$, crude protein $0.40 \%$ and carbohydrate $19.56 \%$. The phytochemical studies on $B$. dalzielii revealed potent antioxidant constituents such as catechin, quercetin, kaermpferol, myricetin, epicatechin, luteolin, alpha-beta-pinene and others (Onoriose, 2012). Aliyu et al(2007) reported that the aqueous extract of B. dalzielii tree bark significantly strengthens the liver and it was recommended in the management of hepatic disorders.Onoriose et al., (2012) reported that the methanolic extract of $B$. dalzielii Hutchcould alleviate the toxic action of $\mathrm{CCl}_{4}$ in the liver of rat.Onobrudu et al(2016) reported that $B$. dalzielii Hutch leaf extract is a potential anti-oxidant modulator for the development of anti-cataract formulation but its safety on the liver of selenite-induced cataract pups has not been

Corresponding Author:- Onobrudu Divine A.

Address:- Institutional Affiliation: Department ofBiochemistry, Faculty of Science, University of Port-

Harcourt, P.M.B 5323, Port-Harcourt, Nigeria. 
studied.Hence, this present study was designed to investigate the effect of themethanol leaf extract of $B$. dalzielii Hutchon the liver integrity of selenite-induced cataract pups.

\section{Methods and Materials:-}

Collection and identification of plant leaves:-

The leaves of Boswellia dalzielii Hutch was obtained from Maitunku hill, Bambam,Dadiya District in Gombe state, Nigeria. Identified and confirmed by Dr. Ekeke Chimezie, University of Port-Harcourt Reference Herbarium for Research and Germplasm Conservation, Department of Plant Science and Biotechnology, University of PortHarcourt, Nigeria and was given the voucher number UPH/V/1247.

\section{Extraction of plant}

Collected leaves were air dried, pulverized and 600 grams of the pulverized plant samples was soaked in $6 \mathrm{~L}$ of methanol, and allowed to stand overnight for 24 hours. Thereafter it was sieved, concentrated using rotary evaporator, weighed and stored in an air tight plastic can.

\section{Experimental animals}

Neonatal Wistar albino rat pups which initially weighed 10-18 $\mathrm{g}$ on the seventh day of age wereobtained together with their dams from Biochemistry Department, University of Port Harcourt. The pups were kept along with their dams in wired cages, at $27 \pm 1{ }^{\circ} \mathrm{C}$.All authors hereby declare that "Principles of laboratory animal care" (NIH publication No. 85-23, revised 1985) were followed, as well as specific national laws where applied.

\section{Experimental design}

A total of 45 neonatal Wistar albino rat pups, initially weighed 10-18 g on the seventh day of age, kept along with their dams in wired cages, were used. They were divided into nine groups comprising of five pups each, such that the difference in weight between one rat group and another was $\pm 1 \mathrm{~g}$. Group 1 received normal saline, groups 2 to 9 received $30 \mu \mathrm{mol} \cdot \mathrm{kg}^{-1} \mathrm{BW}$ of sodium selenite. The $30 \mu \mathrm{mol} \cdot \mathrm{kg}^{-1}$ body weight of sodium selenite was adopted from Mohammed (2012). Eight days post administration of selenite, the presence of cataract was confirmed and the treatment commenced and lasted for 28days. The extract was administered at doses of $300 \mathrm{mg} / \mathrm{kg}$ body weight, 400 $\mathrm{mg} / \mathrm{kg} 500 \mathrm{mg} / \mathrm{kg}, 600 \mathrm{mg} / \mathrm{kg}$ and $700 \mathrm{mg} / \mathrm{kg}$ to groups 5 to 9 respectively; groups 3 and 4 received $50 \mathrm{mg} / \mathrm{kg}$ each of vitamins $\mathrm{A}$ and $\mathrm{C}$ respectively; while groups 1 and 2 received water in place of the extract. At the end of the treatment period, the animals were anaesthetized with chloroform and sacrificed by cutting through their jugular vein. The blood pooled from each rat was collected into labelled plain bottles, centrifuged at $1200 \mathrm{~g}$ for $5 \mathrm{~min}$ and the serum separated into clean plain bottles for biochemical analysis.

\section{Biochemical assays on the serum Serum alkaline phosphatase (ALP) activity}

Serum alkaline phosphatase was determined using the Reflotron Assay method by Roche Diagnostics Ltd, Bell Lane, Lewes, United Kingdom. The principle states that Alkaline phosphatase hydrolyzes O-cresolphthalein phosphate to O-cresolphthalein and transfers the phosphate group to the acceptor molecule methylglucamine. The coloured hydrolysis product $\mathrm{O}$-cresolphthalein that is produced per unit of time under alkaline conditions is directly proportional to alkaline phosphatase activity.

\section{Determination of alanine aminotransferase (ALT) activity}

Serum ALT was determined using the Reflotron Assay method by Roche Diagnostics Ltd, Bell Lane, Lewes, United Kingdom. The principle states that in the presence of ALT, $\alpha$-ketoglutarate and alanine are converted to glutamate and pyruvate. The resultant pyruvate is cleaved by Pyruvate oxidase into acetyl phosphate, carbon dioxide and hydrogen peroxide. Hydrogen peroxide converts an indicator into its oxidized blue form. The formation of the dye is measured kinetically at $567 \mathrm{~nm}$ as a measure of ALT activity

\section{Determination of the aspartate aminotransferase (AST) activity}

Serum aspartate aminotransferase was determined using the Reflotron Assay method by Roche Diagnostics Ltd, Bell Lane, Lewes, United Kingdom. The principle states that in the presence of AST, $\alpha$-ketoglutarate and alanine sulphinate are converted to glutamate and pyruvate. The resultant pyruvate is cleaved by pyruvate oxidase into acetyl phosphate, carbon dioxide and hydrogen peroxide. Hydrogen peroxide converts an indicator into its oxidized blue form. The formation of the dye is measured kinetically at $567 \mathrm{~nm}$ as a measure of AST activity. 


\section{Determination of total protein (TP) concentration}

Serum total protein was determined according to the Biuret method using Randox kit by Randox Laboratotries Ltd, England, and United Kingdom. The principle is based on the fact that cupric ions, in an alkaline medium, react with protein peptide bonds resulting in the formation of a purple coloured complex. The intensity of the final coloured complex is measured colorimetrically at $540 \mathrm{~nm}$ and it is proportional to the concentration of the total protein in the sample.

\section{Determination of serum albumin}

Serum albumin was determined by the Bromocresol green colorimetric method using Randox kit by Randox Laboratotries Ltd, England, United Kingdom. The principle is based on the fact that Bromocresol green is an indicator which is yellow between $\mathrm{pH}$ 3.5-4.2 when it binds to albumin the colour of the indicator changes from yellow to blue green. The absorbance of the albumin-bromocresol green coloured complex is directly proportional to the concentration of albumin at $578 \mathrm{~nm}$.

\section{Determination of serum total bilirubin concentration}

Serum total bilirubin was determined using the Reflotron Assay method by Roche Diagnostics Ltd, Bell Lane, Lewes, United Kingdom. Before the reaction start, the protein bound indirect bilirubin is released by means of dyphilline [7- (2,3-dihydroxypropyl)-theophilline]. Both the direct and the indirect bilirubin react with the diazonium salt 2-methoxy-4-nitrophenyldiazonium. Indirect bilirubin is released by means of dyphilline. The bilirubin concentration is proportional to the dye formed at $567 \mathrm{~nm}$ and $37^{\circ} \mathrm{C}$.

\section{Statistical analysis of data}

Data were expressed as mean \pm standard deviation (SD). The results were analysed statistically by one way analysis of variance (ANOVA), followed by multiple comparison test of least significant difference (LSD). Significance was accepted at a $p$-value of 0.05 .

\section{Results}

Table 1 Effect of the methanol leaf extract of Boswellia dalzielii Hutch on serum indicators of liver integrity in selenite-induced cataract pups

\begin{tabular}{|l|l|l|l|}
\hline Treatment groups & ALP activity(U/L) & AST activity (U/L) & ALT activity(U/L) \\
\hline Normal control & $134.68 \pm 08.61^{\mathrm{a}}$ & $70.28 \pm 06.12^{a}$ & $18.18 \pm 04.61^{a}$ \\
\hline Toxic control & $141.52 \pm 11.08^{\mathrm{a}, \mathrm{c}}$ & $53.40 \pm 10.53^{c}$ & $14.28 \pm 04.29^{a, c}$ \\
\hline Vitamin A treated & $125.00 \pm 15.00^{a, f}$ & $56.50 \pm 11.21^{c}$ & $17.93 \pm 02.31^{a, c, d}$ \\
\hline Vitamin C treated & $145.00 \pm 19.90^{a, c, e}$ & $70.82 \pm 14.48^{a, d}$ & $22.65 \pm 04.78^{d}$ \\
\hline $300 \mathrm{mg} / \mathrm{kg}$ extract & $141.53 \pm 13.28^{a, c, e}$ & $58.90 \pm 03.35^{a, c, d}$ & $16.83 \pm 03.39^{a, c}$ \\
\hline $400 \mathrm{mg} / \mathrm{kg}$ extract & $147.63 \pm 01.61^{a, c, e}$ & $56.38 \pm 14.70^{c}$ & $19.23 \pm 01.30^{a, c, d}$ \\
\hline $500 \mathrm{mg} / \mathrm{kg}$ extract & $124.00 \pm 09.02^{a, f}$ & $53.48 \pm 03.10^{c}$ & $22.08 \pm 02.08^{a, d}$ \\
\hline $600 \mathrm{mg} / \mathrm{kg}$ extract & $143.25 \pm 11.59^{a, c, e}$ & $58.80 \pm 09.51^{a, c, d}$ & $20.30 \pm 06.13^{a, d}$ \\
\hline $700 \mathrm{mg} / \mathrm{kg}$ extract & $147.25 \pm 09.43^{a, c, e}$ & $78.60 \pm 07.23^{a, d, e}$ & $20.28 \pm 05.71^{a, d}$ \\
\hline
\end{tabular}

Data were represented as mean \pm standard deviation of $n=5$ or 4

Values in the same column with different superscript letters (a, b, c, d and f) are significantly different at $p<0.05$

Table 2:- Effect of the methanol leaf extract of Boswellia dalzielii Hutch on serum markers of liver function in selenite-induced cataract pups.

\begin{tabular}{|l|l|l|l|l|}
\hline Treatment groups & Total protein $(\mathbf{g} / \mathbf{d L})$ & Albumin $(\mathbf{g} / \mathbf{d L})$ & Total bilirubin(mg/dL) & Direct bilirubin(mg/dL) \\
\hline Normal control & $03.80 \pm 00.23^{a}$ & $02.88 \pm 00.11^{a}$ & $00.44 \pm 00.05^{a}$ & $00.11 \pm 00.03^{a}$ \\
\hline Toxic control & $04.04 \pm 00.34^{a, c}$ & $02.88 \pm 00.08^{a, c}$ & $00.48 \pm 00.08^{a, c}$ & $00.13 \pm 00.05^{a, b}$ \\
\hline Vitamin A treated & $03.70 \pm 00.30^{a, b}$ & $03.23 \pm 00.58^{a, c}$ & $00.43 \pm 00.05^{c, d}$ & $00.17 \pm 00.06^{a, c, d}$ \\
\hline Vitamin C treated & $03.83 \pm 00.13^{a, b, c}$ & $02.95 \pm 03.52^{d}$ & $00.53 \pm 00.10^{a, c, d}$ & $00.16 \pm 00.05^{a, c}$ \\
\hline $300 \mathrm{mg} / \mathrm{kg}$ extract & $03.83 \pm 00.05^{a, b, c}$ & $02.95 \pm 00.10^{a, c}$ & $00.43 \pm 00.13^{c, d, e}$ & $00.10 \pm 00.02^{\mathrm{a,e}}$ \\
\hline $400 \mathrm{mg} / \mathrm{kg}$ extract & $03.95 \pm 00.31^{a, b, c}$ & $02.93 \pm 00.05^{a, c}$ & $00.38 \pm 00.05^{e}$ & $00.14 \pm 00.06^{a, c, e, f}$ \\
\hline $500 \mathrm{mg} / \mathrm{kg}$ extract & $03.88 \pm 00.15^{a, b, c}$ & $02.90 \pm 00.14^{a, c}$ & $00.53 \pm 00.10^{c, d, f}$ & $00.16 \pm 00.04^{a, c, f}$ \\
\hline $600 \mathrm{mg} / \mathrm{kg}$ extract & $03.85 \pm 00.06^{a, b, c}$ & $02.83 \pm 00.10^{a, c}$ & $00.33 \pm 00.05^{e}$ & $00.09 \pm 00.02^{a, e}$ \\
\hline $700 \mathrm{mg} / \mathrm{kg}$ extract & $03.78 \pm 00.15^{a, b, c}$ & $02.95 \pm 00.13^{a, c}$ & $00.38 \pm 00.05^{e}$ & $00.11 \pm 00.03^{a, e, f}$ \\
\hline
\end{tabular}

Data were represented as mean \pm standard deviation of $n=5$ 
Values in the same column with different superscript letters (a, b, c, d, e and f) are significantly different at $p<0.05$

Table 1 and 2 shows the Effect of the methanol leaf extract of B. dalzielii Hutch on liver function parameters. The ALP activity of the vitamin A and $500 \mathrm{mg} / \mathrm{kg}$ extract treated group showed significant $(p<0.05)$ reduction when compared to the toxic control group. The ALP activity of the extract treated $(300 \mathrm{mg} / \mathrm{kg}, 400 \mathrm{mg} / \mathrm{kg}, 600 \mathrm{mg} / \mathrm{kg}$ and $700 \mathrm{mg} / \mathrm{kg}$ ) and vitamin $\mathrm{C}$ treated groups showed increase when compared to the toxic control group, although the increase was not significant at $(p<0.05)$. The activity of ALP ranged from $124.00 \mathrm{U} / \mathrm{L}$ in $500 \mathrm{mg} / \mathrm{kg}$ extract treated pups to $147.63 \mathrm{U} / \mathrm{L}$ in $400 \mathrm{mg} / \mathrm{kg}$ extract treated group. The plasma AST activity of the vitamin C and $700 \mathrm{mg} / \mathrm{kg}$ extract treated group showed significant $(p<0.05)$ increase when compared to the toxic control group. The AST activity of the $300 \mathrm{mg} / \mathrm{kg}, 400 \mathrm{mg} / \mathrm{kg}, 500 \mathrm{mg} / \mathrm{kg}$ and $600 \mathrm{mg} / \mathrm{kg}$ extract treated and vitamin A treated groups showed non-significant $(p<0.05)$ increase when compared to the toxic control group. The activity of AST (U/L) in the $700 \mathrm{mg} / \mathrm{kg}$ extract treated group $(78.60 \pm 07.23)$ was highest followed by the vitamin $\mathrm{C}$ treated group (70.82 \pm 14.48$)$ and was lowest in the toxic control group (53.40 \pm 10.53$)$.The ALT activity (U/L) was highest in vitamin $\mathrm{C}$ treated group $(22.65 \pm 04.78)$ followed by $500 \mathrm{mg} / \mathrm{kg}$ extract treated group (22.08 \pm 02.08$)$ and was lowest in the toxic control group (14.28 \pm 04.29$)$. The ALT activity of the vitamin C treated and $500 \mathrm{mg} / \mathrm{kg}, 600 \mathrm{mg} / \mathrm{kg}$ and $700 \mathrm{mg} / \mathrm{kg}$ extract treated groups showed significant $(p<0.05)$ increase when compared to the toxic control group, while the ALT activity of the $300 \mathrm{mg} / \mathrm{kg}$ and $400 \mathrm{mg} / \mathrm{kg}$ extract treated, and vitamin A treated groups showed nonsignificant $(p<0.05)$ increase when compared to the toxic control group. As shown (Table 2), the plasma total protein concentration of the vitamin A $(03.70 \pm 0.30)$ treated showed significant $(p<0.05)$ reduction when compared to the toxic control group (04.04 \pm 0.34 ), while the total protein of the $300 \mathrm{mg} / \mathrm{kg}, 400 \mathrm{mg} / \mathrm{kg}, 500 \mathrm{mg} / \mathrm{kg}, 600 \mathrm{mg} / \mathrm{kg}$ and $700 \mathrm{mg} / \mathrm{kg}$ extract and vitamin $\mathrm{C}$ treated groups showed reduction when compared to the toxic control group, although these changes were not significant at $p<0.05$. The plasma albumin concentration of the vitamin $\mathrm{C}$ treated group showed significant $(p<0.05)$ increase when compared to the toxic control groups. Plasma albumin concentration of the $600 \mathrm{mg} / \mathrm{kg}$ extract treated group showed non-significant $(p<0.05)$ reduction when compared to the toxic control group, while $300 \mathrm{mg} / \mathrm{kg}, 400 \mathrm{mg} / \mathrm{kg}, 500 \mathrm{mg} / \mathrm{kg}$ and $700 \mathrm{mg} / \mathrm{kg}$ extract treated and vitamin A treated groups showed non-significant $(p<0.05)$ increase when compared to the toxic control group. Total bilirubin concentration $400 \mathrm{mg} / \mathrm{kg}, 600 \mathrm{mg} / \mathrm{kg}$ and $700 \mathrm{mg} / \mathrm{kg}$ extract treated groups showed significant $(p<0.05)$ reduction, while the vitamin A treated and $300 \mathrm{mg} / \mathrm{kg}$ extract treated groups showed non-significant $(p<0.05)$ reduction when compared to the toxic control group. The total bilirubin concentration of the vitamin C treated and $500 \mathrm{mg} / \mathrm{kg}$ extract treated groups showed non-significant $(p<0.05)$ increase when compared to the toxic control group. The direct bilirubin of the extract treated $(300 \mathrm{mg} / \mathrm{kg}, 600 \mathrm{mg} / \mathrm{kg}$ and $700 \mathrm{mg} / \mathrm{kg}$ ) groups showed reduction when compared to the toxic control group, while $400 \mathrm{mg} / \mathrm{kg}$ and $500 \mathrm{mg} / \mathrm{kg}$ extract treated and vitamins C and A treated group showed increase when compared to the toxic control group. These changes in direct bilirubin were not significant at $(p<0.05)$.

\section{Discussion}

In this study, the treatment produced dose dependent significant increase in serum activities of alanine aminotransferase. However, this was not accompanied by a similar elevation in AST and ALP activities, and therefore did not confirm whether the increase in plasma ALT activities was due to liver inflammatory reactions or damage. Hepatocellular damage that involves the cytoplasmic or mitochondrial membranes is often characterized by increase in the activities of aminotransferase enzymes (Crook, 2006). Plasma enzyme activities of aminotransferases are elevated when the membranes of only very few cells of the hepatocytes are damaged. The raised plasma transaminase concentrations observed in this study are indicative of hepatocyte damage.

The liver responds to any type of hepatobiliary obstruction by inducing ALP synthesis which enters the blood circulation to elevate the level of the enzyme in the serum (Burtis and Ashwood, 2001). Therefore, the reduction in the plasma activities of ALP observed in B. dalzielii treated groups indicates that there was no obstruction of the hepatobiliary system in the experimental pups.

Compared to the toxic control group, the treatment dose dependently lowered the plasma total bilirubin levels of the treated animals, while having no significant effects on the plasma conjugated bilirubin levels. This means that there was no deterioration of the hepatobiliary system, and no compromise of the ability of the liver to take up, process and secrete bilirubin into the bile.

The plasma albumin and total protein levels of the treated animals were higher but not significantly, than those of the toxic control groups at the 5\% level. The increase in the levels of albumin and total protein as observed in this study reflects restoration in the capacity of the liver to synthesize protein. Earlier, studies have reported the ability of the extract to enhance the integrity of the liver (Aliyu et al., 2007), and alleviate liver damage in Wistar rats (Onoriose, 2012). However, the increased levels of plasma ALT activities produced by the high doses of the extract 
confirms earlier concern raised by Abdulazeez et al (2013), that the consumption of B. dalzielii extract at high doses and over a lengthened duration should be done with caution as it seems to compromise the integrity or function of the liver.

\section{Conclusion}

This study revealed that the extracts had no deleterious effect on the liver integrity of selenite induced cataract pups hence it is a potential agent for the management of cataract.

\section{Reference}

1. Abdulazeez, A.T., Kabele-Toge, B., Lawal, M. and Abubakar, M.G. (2013). Phytochemical, antibacterial and Toxicological studies of aqueous stem bark extract of Boswellia dalzielii. African Journal of Pharmaceutical Research Development, 5(1): 61-67.

2. Aliyu, R., Gatsing, D. and Jaryum, K.H. (2007). The effect of Boswellia dalzielii (Buseraceae) aqueous bark extract on rat liver function. Asian Journal of Biochemistry, 2(5):359-363

3. Burtis, C.A. and Ashwood, E.R. (2001). Tiez Fundamentals of Clinical Chemistry. (5 ${ }^{\text {th }}$ d) W. B. Saunders Company, Philadelphia. Pp 352-768.

4. Mitra, S.K., Venkataranganna, M.V., Sundaram, R. and Gopumadhavan, S. (1998), Protective effect of HD-03, a herbal formulation, against various hepatotoxic agents in rats. Journal of Ethnopharmacology, 63:181-186.

5. Mohammed, H.H.H. (2012). Effect of some functional foods on induced cataract in experimental animals. Thesis Submitted for Doctor Philosophy Degree in Science in "Biochemistry and Nutrition", Biochemistry and Nutrition Department, Women's College for Art, Science and Education, Ain Shams University.

6. Onobrudu, D.A., Ikewuchi, J.C. and Onyeike E.N. (2016). Moderation of ocular markers of oxidative stress of selenite induced cataractous pups by Boswellia dazielii Hutch extract. Global Advance Journal of Medicinal Plant. 4(2):007-011

7. Onoriose, D.A. (2012). Phytochemistry and biochemical effect of methanolic extract of Boswellia dalzielii Hutch leaves on carbon tetrachloride induced hepatotoxicity in albino rats. An M.Sc. thesis submitted to the Department of Biochemistry, University of Port-Harcourt. Pp123-133

8. Onoriose, D.A., Uwakwe, A.A. and Monago, C.C. (2012). Hepatoprotective effect of the methanolic leaf extract of Boswellia dalzielii Hutch on carbon tetrachloride induced hepatotoxicity in wistar rats. Indian Journal of Medicine and Healthcare, 1(3): 55-63

9. Rekha, R., Hemalatha, S., Akasakalai, K., Mudhukrisna, C.H., Vittal, S.B. and Sundaram, R.M. (2009). Hepatoprotective activity of Mimosa pudica leaves against $\mathrm{CCl}_{4}$ induced toxicity. Journal of Natural Products, 2:116122

10. Sani, Z. and Qamar, M. (2015). Comparative effects of Boswellia dalzielii parts on survival of adult callosobruchusmaculatus (fabricius) [coleoptera: chrysomelidae] reared on cowpea seeds. Annals of Biological Sciences, 3(2): 1-4

11. Strinath, A., Jyothi, V. and Asha, J.V. (2010). Hepatoprotective activity. International Journal of Pharmacy and Technology, 2(3):354-366.

12. Uzama, D., Gbubele, J.D., Bwai, M.D. and kabir, M.G. (2015). Phytochemistry, nutritional and anti-microbial screening of hexane, ethyl acetate and ethanolic extract of Boswellia dalzielii leaves and bark. American Journal of Bioscience and Bioengineering, 3(5):76-79.

13. Younoussa, L. Elias, N.N., Danga, Y.S.P. and Okechukwu, E. (2014). Larvicidal activity of Annonasenegalensis and Boswellia dalzielii leaf extract against Aedesaegypti (Diptera: colicidac). International Journal of Mosquito Research, 1(4): 25-29 